\title{
Changes in FSH and the pulsatile secretion of LH during the delay in oestrus induced by treatment of ewes with bovine follicular fluid
}

\author{
A. S. McNeilly \\ M.R.C. Reproductive Biology Unit, University of Edinburgh Centre for Reproductive Biology, \\ 37 Chalmers Street, Edinburgh EH3 9EW, U.K.
}

\begin{abstract}
Summary. Treatment of Welsh Mountain ewes with i.v. injections of untreated or charcoal-treated bovine follicular fluid (BFF) after prostaglandin-induced luteal regression resulted in a significant delay in the onset of oestrous behaviour. Injections of BFF caused a significant decrease in plasma concentrations of FSH but levels were only suppressed below those in control ewes during the first $24 \mathrm{~h}$ of the 48 -h period of treatment. At the end of BFF treatment there was a substantial increase in plasma FSH levels. In contrast, there were no significant effects of BFF treatment on basal plasma concentrations of $\mathrm{LH}$ or pulse frequency or amplitude of $\mathrm{LH}$ secretion. Corpus luteum function, as measured by plasma concentrations of progesterone, in BFF-treated ewes was normal. These results suggest that the delay in oestrus caused by treatment of ewes with BFF is due to a specific suppression of plasma levels of FSH while LH secretion remains unaffected.
\end{abstract}

\section{Introduction}

It has been shown that twice daily injections of bovine follicular fluid after prostaglandin-induced luteolysis cause a significant delay in the onset of oestrus in sheep and cows (Miller, Crister, Rowe \& Ginther, 1979). This effect has been attributed to a specific suppression in plasma levels of follicle-stimulating hormone (FSH) since plasma levels of luteinizing hormone (LH) were apparently unaffected (Miller, Crister \& Ginther, 1982). However, LH is released in a pulsatile manner, with pulse frequency increasing during the preovulatory period, in the ewe (see Baird \& McNeilly, 1981). Blood samples in the previous studies (Miller et al., 1982) were withdrawn too infrequently for any effect on this increase in LH pulse frequency to be excluded.

The pulsatile secretion of LH during the preovulatory period in the ewe is essential for the final stages of follicular development (Fraser \& McNeilly, 1983; McNeilly, Fraser \& Baird, 1984) but the precise role of FSH remains unclear (McNatty, 1982; McNeilly et al., 1984). Studies with ovariectomized ewes have confirmed the absence of effect of bovine follicular fluid on pulsatile $\mathrm{LH}$ secretion (Cummins, O'Shea, Bindon, Lee \& Findlay, 1983) but similar studies of cryptorchid rams, using rete testis fluid as the source of inhibin, suggested that the pulsatile secretion of LH could be disturbed (Cahoreau, Blanc, Dacheux, Pisselet \& Courot, 1979).

We have therefore investigated the changes in plasma concentrations of FSH and in pulsatile secretion of LH during the preovulatory period in ewes treated with bovine follicular fluid.

\section{Animals}

\section{Materials and Methods}

Twenty Welsh ewes were used in 3 experiments between November and January. In the first 2 experiments, in which no blood samples were taken during the period of treatment, animals were 
maintained outdoors at pasture under natural lighting at the Animal Breeding Research Organisation, Dryden Field Laboratory, Roslin, Midlothian, U.K. In the third experiment ewes were kept in metabolism crates in a heated room (about $15^{\circ} \mathrm{C}$ ) until the end of the experiment.

\section{Preparation of bovine follicular fluid for injection}

Bovine follicular fluid was aspirated from all visible follicles in ovaries within $4 \mathrm{~h}$ of slaughter at a local abattoir. Pooled follicular fluid was stored at $-20^{\circ} \mathrm{C}$ and was only thawed before injection (Exp. 1) or immediately before charcoal treatment. To remove steroids, batches of follicular fluid of sufficient volume for each experiment were thawed, pooled and stirred with dextran-coated charcoal $(5 \mathrm{mg} / \mathrm{ml})$ for $1 \mathrm{~h}$ at room temperature (about $18^{\circ} \mathrm{C}$ ). The fluid was then centrifuged at $1000 \mathrm{~g}$ for $30 \mathrm{~min}$ at $4^{\circ} \mathrm{C}$ to remove the charcoal and refrozen until required for injection.

After charcoal treatment, concentrations of oestradiol, androstenedione, testosterone and progesterone were all $<5 \mathrm{pg} / \mathrm{ml}$ bovine follicular fluid.

\section{Experimental design}

Experiments 1 and 2. These experiments used untreated follicular fluid (Exp. 1) or charcoaltreated follicular fluid (Exp. 2) to confirm that treatment of ewes caused a delay in the onset of oestrus. In both experiments 20 ewes were treated with progesterone-impregnated vaginal pessaries (Choronogest: Intervet Laboratories, Cambridge, U.K.) to synchronize cycles. At $09: 00 \mathrm{~h}$ on Day 10 of the subsequent cycle, luteal regression was induced in all ewes by i.m. injection $(100 \mu \mathrm{g})$ of cloprostenol, a potent analogue of prostaglandin (PG) F-2 $\alpha$ (Estrumate: ICI, Cheshire, U.K.). Then 10 ewes were given i.v. injections of $5 \mathrm{ml}$ of whole follicular fluid (Exp. 1; November) or charcoal-treated follicular fluid (Exp. 2; December) at the same time as the PG $(09: 00 \mathrm{~h})$ and again at $17: 00 \mathrm{~h}$ on Day 1, with further treatment at $09: 00 \mathrm{~h}$ and 17:00 h on Days 2 and 3 after $P G$. The 10 remaining ewes were untreated and acted as controls.

A raddled vasectomized ram was used to detect oestrus and tests were made at 08:00, 12:00 and $20: 00 \mathrm{~h}$ daily. A single blood sample $(5 \mathrm{ml})$ was withdrawn by venepuncture 10 days after oestrus in all ewes in Exp. 2.

Experiment 3. The 10 control ewes in Exp. 2 were used in Exp. 3 in January to investigate in detail the changes in plasma concentrations of LH and FSH. On the morning of Day 10 of the luteal phase all ewes were fitted with a jugular venous catheter and transferred to individual metabolism crates. Prostaglandin (cloprostenol) was injected as before at 17:00 h and at the same time 5 ewes received an i.v. injection of $5 \mathrm{ml}$ charcoal-treated bovine follicular fluid. These injections of follicular fluid were repeated at $09: 00$ and 17:00 h on the next 2 days (last injection $48 \mathrm{~h}$ after PG). The remaining 5 ewes were injected with saline $(9 \mathrm{~g} \mathrm{NaCl} / \mathrm{l})$ and acted as controls.

Blood samples $(3 \mathrm{ml})$ were withdrawn at 30 -min intervals from $4 \mathrm{~h}$ before until $4 \mathrm{~h}$ after PG injection and then over 8-h periods $16-24,40-48,64-72$ and 88-96 $\mathrm{h}$ after the PG injection until oestrus was detected. In addition, within each 8 -h period of sampling, 10-min blood samples were withdrawn over the middle 4-h period to allow measurement of the pulsatile secretion of LH.

From $32 \mathrm{~h}$ after PG injection the ewes were tested every $8 \mathrm{~h}$ for response to a ram to detect oestrus. At each test, the ewes were removed from the metabolism crates and observed in a pen with a vasectomized ram for $5 \mathrm{~min}$. Once oestrus had been detected, frequent blood sampling was stopped, but blood samples were collected every 2 nd day for 14 days to measure progesterone as an assessment of corpus luteum function.

\section{Hormone assays}

LH and FSH were measured in duplicate in specific double-antibody radioimmunoassays exactly as described previously (McNeilly, McNeilly, Walton \& Cunningham, 1976; Martensz, 
Baird, Scaramuzzi \& Van Look, 1976). The sensitivities of the assay were $0 \cdot 1 \mathrm{ng}$ LH (NIH-LH$\mathrm{S} 18) / \mathrm{ml}$ and $4 \mathrm{ng} \mathrm{FSH}$ (NIH-FSH-S10)/ml. The intra- and inter-assay variations as coefficients of variation $(\%)$ were 5.8 and $9.7 \%$ for $\mathrm{LH}$ and 7.1 and $9.9 \% \mathrm{FSH}$, respectively.

Progesterone concentrations in plasma were measured by the radioimmunoassay described previously (Djahanbahkch, Swanston, Corrie \& McNeilly, 1981) with an intra-assay coefficient of variation of $8.2 \%$ and sensitivity of $0.1 \mathrm{ng} / \mathrm{ml}$. Recovery of progesterone added to sheep plasma was $83 \pm 2 \%$ (s.e.m.; $n=50$ ).

\section{Statistical analysis}

The effects of treatment on onset of oestrus, duration of the luteal phase and characteristics of the pulsatile secretion of LH were analysed using Student's $t$ test. The differences in hormone concentrations between groups on each day of treatment were analysed by 2-way analysis of variance with repeated measures after log transformation. A rise in $\mathrm{LH}$ was considered to be a pulse if the value of two consecutive samples was greater than the mean of the two previous samples (basal value) and the value of at least one of the peak samples exceeded the mean basal value by more than twice the coefficient of variation of the assay (Backström, McNeilly, Leask \& Baird, 1982; McNeilly \& Baird, 1983). Pulse frequency was analysed by $\chi^{2}$ test.

\section{Results}

\section{Oestrous behaviour and subsequent luteal function}

The treatment of ewes with untreated (Exp. 1) or charcoal-treated (Exps $2 \& 3$ ) bovine follicular fluid after PG injection resulted in a significant $(P<0.001)$ delay in the onset of oestrus (Table 1$)$. Whether treatment was given for $72 \mathrm{~h}$ or $48 \mathrm{~h}$, the delay from last injection of bovine follicular fluid to onset of oestrus was similar (mean \pm s.e.m. $71 \pm 3$ and $82 \pm 4$ for 72 -h treatment in Exps $1 \& 2$; $74 \pm 14 \mathrm{~h}$ for 48 -h treatment in Exp. 3). The oestrous cycle length after $72 \mathrm{~h}$ of treatment was significantly $(P<0.05)$ shorter than in controls (Table 1) although plasma levels of progesterone on Day 10 after oestrus of these cycles were not significantly different (control, $3.9 \pm 0.9 \mathrm{ng} / \mathrm{ml}$; treated, $4.1 \pm 0.8 \mathrm{ng} / \mathrm{ml}$ ). No significant difference in length of the luteal phase (Table 1 ) or plasma concentrations of progesterone (Text-fig. 1) were seen after 48 -h treatment with bovine follicular fluid (Exp. 3).

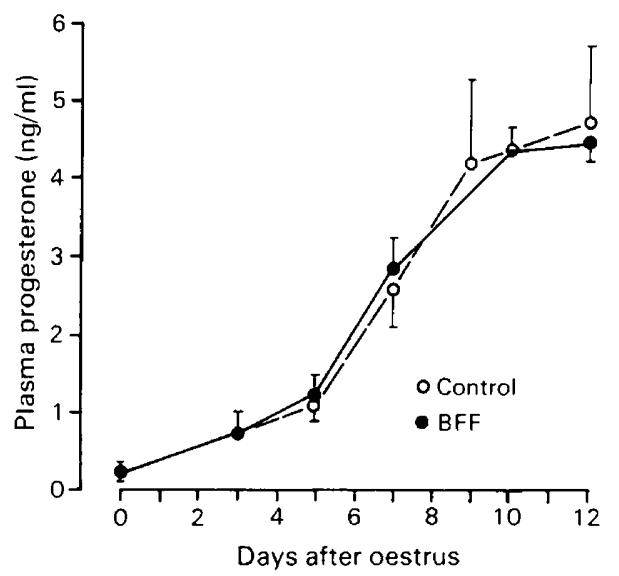

Text-fig. 1. Changes (mean \pm s.e.m.) in the concentration of progesterone after oestrus in untreated ewes or ewes treated with i.v. injections of bovine follicular fluid (BFF) for $48 \mathrm{~h}$ after cloprostenol-induced luteal regression. 
Table 1. Effect of treatment of ewes with whole or charcoal-treated bovine follicular fluid (BFF) for 48 to $72 \mathrm{~h}$ after cloprostenol-induced luteal regression on Day 10 of the luteal phase

\begin{tabular}{|c|c|c|c|c|c|c|c|}
\hline \multirow[b]{2}{*}{ Exp. } & \multirow{2}{*}{$\begin{array}{c}\text { No. of } \\
\text { ewes/group }\end{array}$} & \multirow{2}{*}{$\begin{array}{l}\text { Type of } \\
\text { BFF }\end{array}$} & \multirow{2}{*}{$\begin{array}{l}\text { Treatment } \\
\text { (h) }\end{array}$} & \multicolumn{2}{|c|}{ Time of oestrus (h) } & \multicolumn{2}{|c|}{$\begin{array}{l}\text { Subsequent luteal } \\
\text { phase length (days) }\end{array}$} \\
\hline & & & & Control & BFF & Control & BFF \\
\hline 1 & 10 & Whole & 72 & $49+6$ & $142+3^{* *}$ & $17 \cdot 3+0 \cdot 2$ & $15.8+0.5^{*}$ \\
\hline 2 & 10 & Charcoal-treated & 72 & $57 \pm 2$ & $154 \pm 4^{* *}$ & NA & $\mathrm{NA}$ \\
\hline 3 & 5 & Charcoal-treated & 48 & $46 \pm 7$ & $122 \pm 14^{* *}$ & $17 \cdot 8 \pm 0.4$ & $18 \cdot 3 \pm 1 \cdot 5$ \\
\hline
\end{tabular}

Values are mean \pm s.e.m. Compared to control: ${ }^{*} P<0.005,{ }^{* *} P<0.001$ (Student's $t$ test).

NA, not available since luteal phase artificially terminated by PG treatment on Day 11 .

\section{Concentrations of FSH and $\mathrm{LH}$}

FSH. While PG injection did not significantly alter plasma levels of FSH in control ewes, concomitant injection of bovine follicular fluid resulted in a significant decrease in FSH over the 4-h period after injection (Text-fig. 2a). However, by $16 \mathrm{~h}$ after PG, FSH concentrations were similar in control and treated animals and in both groups were significantly $(P<0 \cdot 01)$ lower than before treatment (Text-fig. 2a). After the second injection of bovine follicular fluid plasma levels of FSH decreased and were significantly $(P<0.001)$ lower than in control ewes $20-24 \mathrm{~h}$ after PG. Since 3 of the 5 control ewes showed oestrus between 24 and $40 \mathrm{~h}$ after PG, only 2 ewes were bled between 40 and $48 \mathrm{~h}$, and so no statistical comparison could be made between FSH values in control
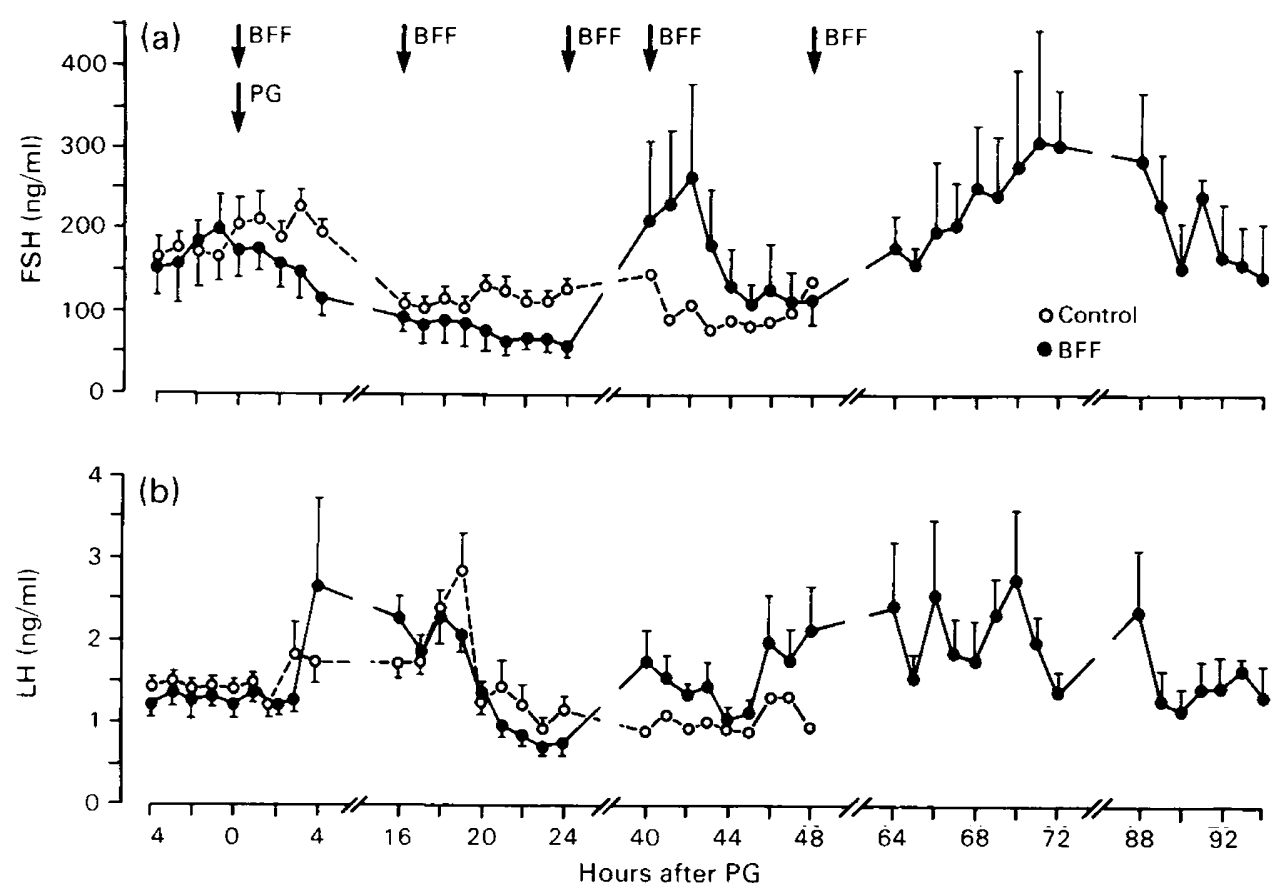

Text-fig. 2. Changes (mean \pm s.e.m.) in the concentrations of (a) FSH and (b) LH after cloprostenol-induced (PG) luteal regression in untreated ewes or ewes treated with i.v. injections of bovine follicular fluid. Blood samples were taken until the onset of oestrous behaviour. The results for control ewes between 40 and $48 \mathrm{~h}$ represent the mean of the 2 ewes that had not shown oestrus by $40 \mathrm{~h}$ after PG. 
and treated ewes at this time. Nevertheless, it is clear that before the 4th injection of bovine follicular fluid at $40 \mathrm{~h}$ after PG, concentrations of FSH were significantly $(P<0.001)$ higher than in the previous 24-h period. A significant decline in FSH concentrations occurred $2 \mathrm{~h}$ after the 4 th injection of bovine follicular fluid (Text-fig. 2a). From $16 \mathrm{~h}$ after the final injection of bovine follicular fluid plasma levels of FSH increased and were similar to those before the 4th injection at $40 \mathrm{~h}$, and were significantly $(P<0.001)$ greater than FSH concentrations at any stage of the preovulatory phase in control ewes (Text-fig. 2a).

$L H$. There were no significant differences between plasma concentrations of $\mathrm{LH}$ in control or treated ewes throughout the preovulatory period. However, basal levels of LH did vary, declining significantly between 18 and $24 \mathrm{~h}$ after PG in both groups of ewes (Text-fig. 2b). In treated ewes LH concentrations were significantly $(P<0.05)$ greater from $64 \mathrm{~h}$ onwards than before $P G$ treatment.

Detailed analysis of the changes in LH during the periods when rapid blood samples were taken confirmed that there were no significant differences between basal concentrations of LH, or pulse frequency or pulse amplitude between control ewes 18-21 h after PG injection and ewes treated with bovine follicular fluid during the period up to $80-83 \mathrm{~h}$ of delay in oestrus (Table 2). However, in control ewes there was a significant $(P<0.05)$ decline in basal concentrations and pulse amplitude of $\mathrm{LH}$, with no change in pulse frequency, between 42 and $45 \mathrm{~h}$ compared to $18-21 \mathrm{~h}$ after PG (paired $t$ test for 2 ewes).

Table 2. Changes in basal concentration, pulse frequency and pulse amplitude of LH after cloprostenolinduced luteal regression in untreated ewes and in ewes treated with i.v. injections of bovine follicular fluid (BFF) for $48 \mathrm{~h}$ (Exp. 3)

\begin{tabular}{|c|c|c|c|c|c|c|}
\hline \multirow{2}{*}{$\begin{array}{l}\text { Time after } \\
\text { cloprostenol } \\
\text { (h) }\end{array}$} & \multicolumn{2}{|c|}{ Basal LH conc. (ng/ml) } & \multicolumn{2}{|c|}{ LH pulses $/ 3 \mathrm{~h}$} & \multicolumn{2}{|c|}{ LH pulse amplitude $(\mathrm{ng} / \mathrm{ml})$} \\
\hline & Control & BFF & Control & BFF & Control & BFF \\
\hline $18-21$ & $1.61 \pm 0.11$ & $1 \cdot 29 \pm 0 \cdot 15$ & $2 \cdot 8 \pm 0.2$ & $2.8 \pm 0.5$ & $0.99 \pm 0.15$ & $0 \cdot 88 \pm 0 \cdot 15$ \\
\hline $42-45$ & $0.89 \pm 0.04^{*}$ & $1 \cdot 03 \pm 0.10$ & $2 \cdot 5 \pm 0.2^{*}$ & $2 \cdot 2 \pm 0.6$ & $0.31 \pm 0.04^{*}$ & $1 \cdot 27 \pm 0 \cdot 14$ \\
\hline $56-59$ & - & $1.30 \pm 0.13$ & - & $2 \cdot 6 \pm 0.3$ & - & $1 \cdot 36 \pm 0 \cdot 26$ \\
\hline $80-83$ & - & $1.01 \pm 0.08$ & - & $2 \cdot 8 \pm 0 \cdot 3$ & - & $0.99 \pm 0.15$ \\
\hline
\end{tabular}

Values are mean \pm s.e.m. for 5 ewes except as indicated otherwise.

* Only 2 ewes represented (see text).

\section{Discussion}

The results of the present study confirm a previous observation that the injection of bovine follicular fluid during the preovulatory phase in the sheep oestrous cycle delays the onset of oestrus (Miller et al., 1979). Once the injections of bovine follicular fluid had ceased, oestrus occurred around $72 \mathrm{~h}$ later. Corpus luteum function in the subsequent luteal phase appeared to be normal, at least in terms of plasma levels of progesterone. In the present experiments the changes in plasma concentrations of LH and FSH have been studied in greater detail than was previously reported (Miller et al., 1982). The injection of bovine follicular fluid into intact ewes caused a significant suppression in plasma levels of FSH compared to controls over the first $24 \mathrm{~h}$ without affecting either basal levels, or pulse frequency and amplitude of $\mathrm{LH}$, confirming previous results in ovariectomized ewes (Cummins et al, 1983). Indeed there was no significant difference in LH secretion between control and bovine follicular fluid-treated ewes during the period of observation. The pulse frequency of $\mathbf{L H}$ increased in a similar manner in treated and control animals and was maintained at this increased frequency throughout the period of delay until oestrus. Since each pulse of LH occurs in response to a release of LH-releasing hormone (LHRH) from the hypothalamus (Clarke \& Cummins, 1982; Fraser \& McNeilly, 1983) the failure of bovine follicular 
fluid to affect the pulsatile secretion of $\mathrm{LH}$ confirms that the suppressive effects on FSH secretion are specific and occur directly at the pituitary at least in the ewe (Cummins et al., 1983).

Oestrus occurs as a result of increasing oestradiol secretion from the developing preovulatory follicle (see Baird \& McNeilly, 1981). Therefore the failure to show oestrus must suggest a failure of the preovulatory follicle to produce normal amounts of oestradiol. This oestradiol is formed by the conversion of androgens released from the theca in response to pulses of LH by the aromatase enzyme system within the granulosa cells of the preovulatory follicle (Baird, Swanston \& McNeilly, 1981 ; McNeilly et al., 1984). Since pulsatile secretion of LH continues during the delay of oestrus it may be presumed that androgens are released but are not converted to oestrogens within the follicle.

The preovulatory follicle in the ewe appears to develop from a pool of follicles around 2-4 $\mathrm{mm}$ in diameter which are present at the time of luteal regression and contain granulosa cells with only limited aromatase activity (McNatty, 1982). In-vitro evidence suggests that in the sheep (McNatty, 1982), as in other species (Hillier, 1981), FSH is required for the increase in granulosa cell aromatase activity which normally occurs during preovulatory follicular development and results in the increase in preovulatory oestradiol secretion by increasing the conversion of thecal androgens (Baird \& McNeilly, 1981; McNatty, 1982). The present study would support this concept in that the reduction in plasma levels of FSH induced by bovine follicular fluid were sufficient to delay oestrus. It has been shown that there is a failure of follicles to show the normal increase in diameter associated with the preovulatory phase during the period of oestrus delay in ewes treated with bovine follicular fluid (Miller et al., 1979).

The decrease in FSH secretion in the present study is similar to that seen after injection of porcine follicular fluid in monkeys (Channing, Anderson, Hoover, Gagliano \& Hodgen, 1981) which also resulted in a failure of normal follicular growth. The studies imply that even small reductions in the normal plasma levels of FSH can cause significant alterations in follicle growth.

In spite of continued injections of bovine follicular fluid, after $40 \mathrm{~h}$ of injections plasma levels of FSH were significantly higher than at $24 \mathrm{~h}$. Other studies (J. Wallace \& A. S. McNeilly, unpublished observations) have shown that a single injection of bovine follicular fluid into intact ewes maintains the suppression of FSH for up to $15 \mathrm{~h}$. This increase in FSH at $40 \mathrm{~h}$ therefore appears to represent a decrease in sensitivity to bovine follicular fluid. Nevertheless, the injection of bovine follicular fluid at $40 \mathrm{~h}$ did cause a significant decline in FSH although the response was delayed and plasma levels of FSH did not decline to the same extent as in the previous $24 \mathrm{~h}$. A similar delay in FSH response was seen in rats after the injection of porcine follicular fluid (Campbell \& Schwartz, 1979). The failure of the later injections of bovine follicular fluid to suppress FSH to the same low levels those seen after earlier injections occurs at a time when it is surmized that ovarian oestradiol secretion will be reduced. In rats the reduction in plasma levels of FSH by follicular fluid is enhanced by oestrogen (Bronson \& Channing, 1978). Oestradiol alone in the ewe, while suppressing FSH (Fraser, Clarke \& McNeilly, 1981; Platt, Foster, Tarnavsky \& Reeves, 1983; Clarke, Cummins \& de Kretser, 1983), will not suppress levels in ovariectomized ewes to those seen in the normal oestrous cycle (Goodman, Pickover \& Karsch, 1981). Since both oestradiol and inhibin, which is presumably the active material in the bovine follicular fluid used in the present study (de Jong \& Sharpe, 1976), increase in parallel with development of the preovulatory follicle in the sheep (Tsonis et al., 1983), it is probable that oestradiol and inhibin act together to induce the suppression of FSH during the cycle. Androgens do not appear to be implicated (McNeilly et al., 1984).

When injections of bovine follicular fluid were stopped, plasma FSH concentrations increased dramatically with oestrus occurring some $72 \mathrm{~h}$ later. After luteal regression in the normal cycle, there is a gradual increase in the frequency of LH pulses towards the preovulatory LH surge (Baird et al., 1981; McNatty, Gibb, Dobson \& Thurley, 1981). Pulsatile secretion is important to stimulate and maintain oestradiol secretion in the preovulatory period in the ewe (Baird, 1978; Baird et al., 1981; McNeilly et al., 1984) and ovulation can be induced in anoestrous ewes by pulsatile injection 
of LH at an increasing frequency (McNatty et al., 1981; McNeilly, O'Connell \& Baird, 1982). However, the increase in frequency may not be important since in the present study follicular growth occurred while LH pulse frequency was at a maximum. Similarly, ovulation can be induced in anoestrous ewes by the pulsatile injection of LH or LHRH at a constant frequency (McNeilly et al., 1982; McLeod, Haresign \& Lamming, 1982).

The present study has shown that the injection of bovine follicular fluid in the preovulatory period in the ewe delays the onset of oestrus in association with a suppression of plasma levels of FSH. The pulsatile secretion of LH was not affected. The consequence of these changes upon the follicles within the ovary remains to be determined.

I thank Miss N. Anderson, Mr B. Ogilvie and Mr I. Swanston for skilled technical assistance; the NIADDK (Bethesda, Maryland, U.S.A.), Dr S. S. Lynch Dr J. E. T. Corrie and Professor M. Jutisz for hormones and antiserum used in the radioimmunoassays; the staff at Dryden Field Station; Mr T. McFetters and Mr F. Pinner for preparation of the figures; Mrs P. Warner for statistical advice; and Mrs A. Shaw for typing the manuscript.

\section{References}

Backström, C.T., McNeilly, A.S., Leask, R.M. \& Baird, D.T. (1982) Pulsatile secretion of LH, FSH, prolactin, oestradiol and progesterone during the menstrual cycle. Clin. Endocr. 17, 29-42.

Baird, D.T. (1978) Pulsatile secretion of LH and ovarian estradiol in the follicular phase of the sheep estrous cycle. Biol. Reprod. 18, 359-364.

Baird, D.T. \& McNeilly, A.S. (1981) Gonadotrophic control of follicular development and secretion in the sheep oestrous cycle. J. Reprod. Fert., Suppl. 30, 119 . 133.

Baird, D.T., Swanston, I.A. \& McNeilly, A.S. (1981) Relationship between LH, FSH and prolactin concentration and the secretion of androgens and estrogens by the preovulatory follicle in the ewe. Biol. Reprod. 24, 1013-1025.

Bronson, F.H. \& Channing, C.P. (1978) Suppression of serum follicle-stimulating hormone by follicular fluid in the maximally estrogenized, ovariectomized mouse. Endocrinology 103, 1894-1898.

Cahoreau, C., Blanc, M.R., Dacheux, J.L., Pisselet, C. \& Courot, M. (1979) Inhibin activity in ram rete testis fluid: depression of plasma FSH and LH in the castrated and cryptorchid ram. J. Reprod. Fert., Suppl. 26, 97-116.

Campbell, C.S. \& Schwartz, N.B. (1979) Time course of serum FSH suppression in ovariectomized rats injected with porcine follicular fluid (folliculostatin): effect of estradiol treatment. Biol. Reprod. 20, 10931098.

Channing, C.P., Anderson, L.D., Hoover, D.J., Gagliano, P. \& Hodgen, G. (1981) Inhibitory effects of porcine follicular fluid on monkey serum FSH levels and follicular maturation. Biol. Reprod. 25, 885-903.

Clarke, I.J. \& Cummins, J.T. (1982) The temporal relationship between gonadotropin releasing hormone $(\mathrm{GnRH})$ and luteinizing hormone (LH) secretion in ovariectomized ewes. Endocrinology 111, $1737-1739$.

Clarke, I.J., Cummins, L.J. \& de Kretser, D.M. (1983) Pituitary gland function after disconnection from direct hypothalamic influences in the sheep. Neuroendocrinology 36, 376-384.

Cummins, L.J., O'Shea, T., Bindon, B.M., Lee, V.W.K. \& Findlay, J.K. (1983) Ovarian inhibin content and sensitivity to inhibin in Booroola and control strain Merino ewes. J. Reprod. Fert. 67, 1-7.

de Jong, F.H. \& Sharpe, R.M. (1976) Evidence for inhibin-like activity in bovine follicular fluid. Nature, Lond. 263, 71-72.

Djahanbahkch, O., Swanston, I.A., Corrie, J.E.T. \& McNeilly, A.S. (1981) Prediction of ovulation by progesterone. Lancet ii, 1164-1165.

Fraser, H.M. \& McNeilly, A.S. (1983) Differential effects of LH-RH immunoneutralization on LH and FSH secretion in the ewe. J. Reprod. Fert. 69, 569-577.

Fraser, H.M., Clarke, I.J. \& McNeilly, A.S. (1981) Effect of oestrogen and LH-RH agonist on the release of gonadotrophins in ovariectomized ewes deprived of ' LH-RH. J. Reprod. Fert. 62, 131-140.

Goodman, R.L., Pickover, S.M. \& Karsch, F.J. (1981) Ovarian feedback control of follicle-stimulating hormone in the ewe: evidence for selective suppression. Endocrinology 108, 772-777.

Hillier, S.G. (1981) Regulation of follicular oestrogen biosynthesis: a survey of current concepts. J. Endocr. 89, $3 P-18 P$

Martensz, N.D., Baird, D.T., Scaramuzzi, R.J. \& Van Look, P.F.A. (1976) Androstenedione and the control of luteinizing hormone in the ewe during anoestrus. J. Endocr. 69, 227-237.

McLeod, B.J., Haresign, W. \& Lamming, G.E. (1982) The induction of ovulation and luteal function in seasonally anoestrous ewes treated with small-dose multiple injections of Gn-RH. J. Reprod. Fert. 65, 215-221.

McNatty, K.P. (1982) Ovarian follicular development from the onset of luteal regression in human and sheep. In Follicular Maturation and Ovulation, pp. 1-18. Eds R. Rolland, E. V. van Hall, S. G. Hillier, K. P. McNatty \& J. Schoemaker. Excerpta Medica, Amsterdam 
MeNatty, K.P., Gibb, M., Dobson, C. \& Thurley, D.C. (1981) Evidence that changes in luteinizing hormone secretion regulate the growth of the preovulatory follicle in the ewe. J. Endocr. 90, 375-389.

McNeilly, A.S. \& Baird, D.T. (1983) Direct effect of prolactin, induced by TRH injection, on ovarian oestradiol secretion in the ewe. J. Reprod. Fert. 69, 559-568.

McNeilly, J.R., McNeilly, A.S., Walton, J.S. \& Cunningham, F.J. (1976) Development and application of a heterologous radioimmunoassay for ovine follicle stimulating hormone. J. Endocr. 70, 69-79.

MeNeilly, A.S., O'Connell, M. \& Baird, D.T. (1982) Induction of ovulation and normal luteal function by pulsed injections of luteinizing hormone in anestrous ewes. Endocrinology 110, 1292-1299.

McNeilly, A.S., Fraser, H.M. \& Baird, D.T. (1984) Effect of immunoneutralization of LH releasing hormone on LH, FSH and ovarian steroid secretion in the preovulatory phase of the oestrous cycle in the ewe. $J$. Endocr. 101, 213-219.

Miller, K.F., Crister, J.K., Rowe, R.F. \& Ginther, O.J. (1979) Ovarian effects of bovine follicular fluid treatment in sheep and cattle. Biol. Reprod. 21, 537544.

Miller, K.F., Crister, J.K. \& Ginther, O.J. (1982) Inhibition and subsequent rebound of FSH secretion following treatment with bovine follicular fluid in the ewe. Theriogenology 18, 45-53.

Platt, T.E., Foster, G.S., Tarnavsky, G.K. \& Reeves, J.J. (1983) Effects of photoperiod and estradiol on tonic gonadotropins in ovariectomized ewes. J. Anim. Sci. 56, 1180-1185.

Tsonis, C.G., Quigg, H., Lee, V.W.K., Leversha, L., Trounson, A.O. \& Findlay, J.K. (1983) Inhibin in individual ovine follicles in relation to diameter and atresia. J. Reprod. Fert. 67, 83-90.

Received 23 January 1984 